Spring 2001

\title{
The Accountability of Government Networks
}

Anne-Marie Slaughter

Harvard Law School

Follow this and additional works at: https://www.repository.law.indiana.edu/ijgls

Part of the Administrative Law Commons, and the International Law Commons

\section{Recommended Citation}

Slaughter, Anne-Marie (2001) "The Accountability of Government Networks," Indiana Journal of Global Legal Studies: Vol. 8 : Iss. 2 , Article 5.

Available at: https://www.repository.law.indiana.edu/ijgls/vol8/iss2/5

This Symposium is brought to you for free and open access by the Law School Journals at Digital Repository @ Maurer Law. It has been accepted for inclusion in Indiana Journal of Global Legal Studies by an authorized editor of Digital Repository @ Maurer Law. For more information, please contact rvaughan@indiana.edu.

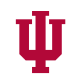

JEROME HALL LAW LIBRARY

INDIANA UNIVERSITY

Maurer School of Law
Bloomington 


\title{
The Accountability of Government Networks
}

\author{
ANNE-MARIE SLAUGHTER*
}

Administrative agencies are networking with their counterparts worldwide." These "government networks," or, more generally, "transgovernmental regulatory networks," are attracting increasing attention and concern. ${ }^{2}$ For some, they herald a new and attractive form of global governance, enhancing the ability of States to work together to address common problems without the centralized bureaucracy of formal international institutions. ${ }^{3}$ They are fast, flexible, and decentralized-attributes that allow them to function particularly well in a rapidly changing information environment. For others, however, these networks portend a vast technocratic conspiracy - a shadowy world of regulators bent on "de-politicizing" global

- J. Sinclair Amstrong Professor of International, Foreign, and Comparative Law, Harvard Law School.

1. See, e.g., Scott H. Jacobs, Regulatory Ca-operation for an Interdependent World: Issues for Government, in REGULATORY CO-OPERATION FORAN INTERDEPENDENT WORLD 15-38 (Org. For Econ. Cooperation \& Dev., 1994); Anne-Marie Slaughter, Governing the Global Economy through Government Networks, in THE ROLE OF LAW IN INTERNATIONAL POLmCS: ESSAYS IN INTERNATIONAL RELATIONS AND INTERNATIONAL LAW 177 (Michael Byers ed., 2000) [hereinafter Slaughter, Governing the Global Economy]; Sol Picciotto, Fragmented States and International Rules of Law, 6 SOC. \& LEGAL STUD. 259 (1997) [hereinafter Picciotto, Fragmented States]; Sol Picciotto, Networks in International Economic Integration: Fragmented States and the Dilemmas of Neo-Liberalism, 17 Nw. J. L. \& Bus. 1014 (1996-97) [hereinafter Picciotto, Networks in Intemational Economic Integration]; Anne-Marie Slaughter, The Real New World Order, 76 Foreign AfF. 183 (1997) [hereinafter Slaughter, Real New World Order]; ThOMAS RISSE-KAPPEN, COOPERATION AMONG DEMOCRACIES 38 (1995) (defining "transgovemmental coalitions" as "transboundary networks among subunits of national governments forming in the absence of central and authoritative national decisions"). Risse-Kappen further defines "transgovernmental networks" as those among state officials in sub-units of national govemments, international organizations, and regimes frequently pursuing their own agenda, independently from and sometimes contrary to the declared policies of their national governments. $I d$. at $38-40$. Finally, he insists that in a genuine transgovernmental regime, "[s]ub-units of national governments have to act on their own, in the absence of national decisions, not just on behalf of their heads of state implementing agreed-upon policies." Id. at 9 . When this occurs, "[t]ransgovernmental coalitions are then defined as networks of government officials which include at least one actor pursuing her own agenda independent of national decisions." Id.

2. Various authors have various names for these networks; in my terminology they are a subset of the larger and growing phenomenon of "government networks:" networks of different types of government institutions from courts to legislatures. See Anne-Marie Slaughter, Judicial Globalization, 40 VA. J. INT'L L. 1103 (2000). See also Slaughter, Real New World Order, supra note 1, at 184.

3. See Slaughter, Real New World Order, supra note 1, at 186, 195. See also Slaughter, Governing the Global Economy, supra note 1, at 177-81. I continue to argue the merits of this form of govemance; however, I am increasingly aware of the actual and potential problems associated with these networks. Hence the importance of focusing on accountability. 
issues in ways that will inevitably benefit the rich and powerful at the expense of the poor and weak. ${ }^{4}$

These competing perspectives come to a head on the issue of accountability. While both corporations and civic institutions such as nongovernmental organizations (NGOs) are networking to attain genuine global reach, networks of government agencies involve public officials and at least some exercise of the governmental power granted to them. Determining how to hold these officials democratically accountable becomes a paramount concern.

Consider the following critiques. Philip Alston argues that the formation of these networks "suggests a move away from arenas of relative transparency into the back rooms," and hence "the bypassing of the national political arenas to which the United States and other proponents of the importance of healthy democratic institutions attach so much importance." 5 Antonio Perez similarly worries about an open "move toward technocratic elitism." Sol Picciotto diagnoses the problem as a "chronic lack of legitimacy," stemming from the informality and confidentiality of transgovernmental contacts. As he notes, these are "precisely the attributes that make them so attractive to the participants." Finally, from Stephen Toope: "Networks, like regimes, and regardless of their membership, are sites of power, and potentially of exclusion and inequality. . . I Indeed, as typically subterranean creatures, operating outside the realm of public scrutiny, governance networks may be even less accountable than some States."

The immediate and conventional response to these accountability concerns is to "increase transparency" by making decisions and documents widely

4. See, e.g. Picciotto, Fragmented States, supra note 1, at 273 (dispersal of politics into functional arenas "appears to allow particular issues to be regulated in a depoliticized, technocratic maner, by managers or professionals who are directly accountable to their 'customers"'); see also Picciotto, Networks in Intemational Economic Integration, supra note 1, at 1037.

5. Philip Alston, The Myopia of the Handmaidens: International Lawyers and Globalization, 8 EUR. J. INT'L L. 435, 441 (1997).

6. Antonio F. Perez, Who Killed Sovereignty? Or: Changing Norms Concerning Sovereignty In International Law, 14 WIS. INT'L L. J. 463, 476 (1996) (book review). Perez is not addressing transgovernmental regulatory networks per se, but rather a related argument about networks among national and international bureaucrats advanced by Abram and Antonia Chayes. See generally ABRAM ChA YES \&

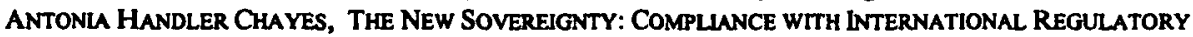
AGREEMENTS (1995).

7. Picciotto, Networks in International Economic Integration, supra note 1, at 1047.

8. Stephen J. Toope, Emerging Patterns of Governance and International Law, in THE ROLE OF LAW, supra note 1 , at $91,96-97$. 
available to interested groups. But, as Joseph Weiler notes, within the European Union (EU):

It is time to worry about infranationalism-a complex network of middle-level national administrators, [European] Community administrators and an array of private bodies with unequal and unfair access to a process with huge social and economic consequences to everyday life-in matters of public safety, health, and all other dimensions of socioeconomic regulation. Transparency and access to documents are often invoked as a possible remedy to this issue. But if you do not know what is going on, which documents will you ask to see?

To think seriously about the question of accountability requires a more systematic and careful analysis of both the different types of accountability and the different types of government networks. This Article distinguishes between national and global accountability and among government networks that operate in existing international organizations, within the framework of a treaty, and outside any preexisting formal framework. By attempting to build a conceptual framework, this Article seeks to contextualize specific problems for the ultimate purpose of creating, developing, or adapting accountability mechanisms. But it will inevitably beg as many questions as it answers.

To begin with, this rudimentary framework relies on an essentially commonsense understanding of "accountability," meaning that those who exercise power on behalf of others can be held accountable if that power is misused or abused. U.S. administrative law, and indeed comparative administrative law, has spent decades grappling with the definition and conceptualization of accountability, as well as with a host of different mechanisms designed to enhance agency accountability, legitimacy, and responsiveness without sacrificing effectiveness. But here administrative law intersects international law and forces international lawyers to look within the State, while international law intersects administrative law and poses questions of global equity. This Article offers an overview of those twin points of

9. Joseph Weiler, To Be a European Citizen: Eros and Civilization, in THE CONSTITUTION OF EUROPE: “DO THE NEW Clothes HAVE AN EMPEROR?” AND OtHER ESSAYS ON EUROPEAN INTEGRATION 324, 349 (Joseph Weiler ed., 1999). 
intersection and suggests a possible starting point for considering and addressing the various problems clumped under the umbrella of "accountability."

\section{A Short AND SElective History of TRANSGOVERNMENTALISM}

Analysts have spent more time identifying and labeling government networks than distinguishing between them. Government networks are typically identified as part of the larger phenomenon of "transnationalism." Philip Jessup introduced international lawyers to "transnational law" in 1958, defining it as "all law which regulates actions or events that transcend national frontiers. Both public and private international law are included, as are other rules which do not wholly fit into such standard categories." ${ }^{10}$ Henry Steiner and Detlev Vagts later translated this concept into a casebook, collecting materials designed to bridge the gap between the domestic and international legal worlds."

Political scientists embraced transnational relations somewhat later, in the late 1960s and 1970s. They acknowledged the plethora of nontraditional actors in the international system and tried to relate them to both States and international organizations. The theoretical debate initially focused on whether to define transnationalism in terms of the identity of the actors or the nature of the activity. In the influential edited volume Transnational Relations and World Politics, Keohane and Nye defined transnational relations as "contacts, coalitions, and interactions across [S]tate boundaries that are not controlled by the central foreign policy organs of government."12 Samuel Huntington responded to this idea by arguing that the definition of transnational relations should focus not on the actors involved in the process, but rather on the

10. Philup C. Jessup, Transnational Law 2 (1956). In footnote 3 of the first chapter, Jessup cites Joseph Johnson as one of the originators of the term in an address of June 15, 1955 to the Harvard Foundation. Id. at n.3.

11. Transnational Legal Problems xv-xvi (Henty J. Steiner \& Detlev F. Vagts, eds., 2d ed. 1976). Steiner and Vagts built on Jessup's broad definition and focused on topics including aspects of national legal systems dealing with principles and procedures for decision-making that have been specifically developed to regulate problems with some foreign element. The relevant participants in transnational activity include "private individuals or firms, national courts or legislators or treaty-makers, governmental instrumentalities, international officials, or regional and international organizations." Id. at xvii.

12. Transnational Relations and WORld Polmtics xi (Joseph S. Nye, Jr. \& Robert O. Keohane, eds., 1972) [hereinafter TRANSNATIONAL RELATIONS]. They identify a separate subset of "transnational interactions" as "the movement of tangible or intangible items across state boundaries when at least one actor is not an agent of a government or an intergovernmental organization." Id. at xii. 
activity itself. He viewed transnationalism as a peculiarly "American mode of expansion," based on "freedom to operate" rather than "power to control."13

Several years later, Keohane and Nye explicitly distinguished "transgovernmental" activity from the broader category of transnational activity, defining "transgovernmental relations" as "sets of direct interactions among sub-units of different governments that are not controlled or closely guided by the policies of the cabinets or chief executives of those governments." 14 They quoted Francis Bator for the proposition that "it is a central fact of foreign relations that business is carried on by the separate departments with their counterpart bureaucracies abroad, through a variety of informal as well as formal connections."15 Their principal interest in this article was to identify the various ways in which the existence of transgovernmental politics, as well as transnational politics, offered ways for international organizations to play an important role in world politics. ${ }^{16}$ Nevertheless, they identified different types of transgovernmental activity (policy coordination and coalition-building), enumerated the conditions under which transgovernmental networks are most likely to form, and specified different types of interactions between international organizations and transgovernmental networks.

Prominent international relations theorists largely lost interest in transnational and transgovernmental relations during the 1980s and early 1990s when interest focused primarily on security studies and interstate "regimes." Over the course of the 1990s, however, several events cast a spotlight on a new generation of transgovernmental networks. As the bipolar State system of the Cold War disappeared and nonstate, substate, and supranational actors rode the tide of globalization, many pundits and scholars

13. Samuel Huntington, Transnational Organizations in World Politics, 25 WORLD POL. 333, 344 (1973).

14. Robert O. Keohane \& Joseph S. Nye, Jr., Transgovernmental Relations and International Organizations, 27 WORLD POLmCs 39, 43 (1974) [hereinafter Transgovernmental Relations]. They included in their definition the increased communication between governmental agencies and business carried on by separate departments with their counterpart bureaucracies abroad. Id. at 41-42. By contrast, a meeting of heads-of-state at which new initiatives are taken was still the paradigm of the state-centric (interstate) model. Id. at 43-44. Compare their earlier depiction of traditional "interstate" relations, in which "actors are behaving in conformity to roles specified or reasonably implied by the formal foreign policy structure of the state." TRANSNATIONAL RELATIONS, supra note 12, at 383.

15. Transgovernmental Relations, supra note 14, at 42 (quoting U.S. Foreign Economic Policy: Implications for the Organization of the Executive Branch: Hearing before the Subcomm. on Foreign Economic Policy of the House Comm. on Foreign Affairs, 92d Cong. 110-11 (July 25, 1972) (testimony of Francis M. Bator, Professor of Political Economy, Harvard University)).

16. Id. 
began heralding the era of complex, multilevel global governance, tied together by networks. ${ }^{17}$ Early on, Peter Haas explored the role and power of "epistemic communities," loose groups of policymakers, NGOs, scientists, and other actors driven by an interest in a particular issue area, such as climate change or human rights. ${ }^{18}$ Later work absorbed the insights gained about the power of shared learning and knowledge production generated by the epistemic communities literature, but concentrated on more concrete and observable organizational forms.

Several convergent factors focused growing attention on the more specific phenomenon of transgovernmental regulatory networks. First were the observable changes in the organization and activities of national financial regulators. The Basle Committee on Banking Supervision (the Basle Committee) was created in 1974 and now comprises the representatives of twelve central banks that regulate the world's largest banking markets. ${ }^{19}$ Between 1975 and 1992, it issued the Basle Concordat with several sets of subsequent amendments, to enhance cooperation between regulators of multinational banks by dividing specified tasks between home country and host country regulators. In 1988, the Basle Committee issued a set of capital adequacy standards to be adopted by its members as the new regulatory standard within their countries. These standards had a sharp impact on the availability of credit in the world's most important economies. ${ }^{20}$ The

17. See generally Thomas Friedman, The LeXus and the Olive Tree (1999); Governance Wrthout Government: ORder and Change IN WORLd Polmtics (James N. Rosenau \& Emst-Otto Czempiel eds., 1992); JAMES ROSENAU, ALONG THE DOMESTIC-FOREIGN FrONTIER (1997). For an excellent review of much of the govemance literature, see Gerry Stoker, Governance as Theory: Five Propositions, 50 INT'L SOC. SCI. J. 17 (1998). For an influential discussion of multi-level governance within the EU, see Fritz W. Scharpf, Community Policy and Autonomy: Multilevel Policymaking in European Union (EUl Working Paper RSC No. 94/1, 1994).

18. See, e.g. Peter M. HaAs, Institutions for the Earth (1993); Peter M. HaAs, INTERNATIONAL

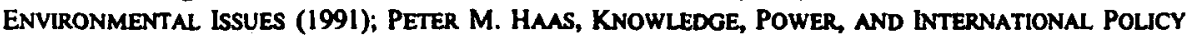
COORDination (1997); Peter M. HaAs, Saving the Mediterranean: The Polutics of INTERNational. ENVIRONMENTAL COOPERATION (1990).

19. The Basle Committee is now known as the International Monetary and Financial Committee (as of 30 September 1999); its members are the Govemors for Algeria, Argentina, Australia, Belgium, Brazil, Canada, China, Finland, France, Gabon, Germany, India, Italy, Japan, Malaysia, the Netherlands, Russia, Saudi Arabia, South Africa, Spain, Switzerland, the United Arab Emirates, the United Kingdom, and the United States. See International Monetary Fund (IMF), A Brief Guide to Committees, Groups, and Clubs: A Factsheet, available at http:/www.imf.org/external/np/exr/facts/groups.htm\#IC (last visited May 15, 2001) [hereinafter MMF Factsheet].

20. TONy Porter, States, Markets and Regimes in Global Finance 3 (1993). See also David Zaring, International Law by Other Means: The Twilight Existence of International Financial Regulatony Organizations, 33 TEX. INT'L L. J. 281, 284 (1998) (describing charge by SEC chair Breeden that the Basle Committee agreement had contributed greatly to world recession). 
International Organization of Securities Commissioners (IOSCO) emerged in 1984, followed in the 1990s by the International Association of Insurance Supervisors and later by the Financial Stability Forum, a network of all three of these organizations and other national and international officials responsible for financial stability around the world. ${ }^{21}$ As several scholars point out, these "organizations" do not fit the model of an organization held either by international lawyers or political scientists-they are not composed of States and constituted by treaty, they do not enjoy legal personality, and they have neither headquarters nor even stationery.22 According to Sol Picciotto, however, they do "form part of a more general shift from 'government' to 'governance,' involving the delegation or transfer of public functions to particularized bodies, operating on the basis of professional or scientific techniques." $^{\text {"23 }}$

A second major impetus for the study of transgovernmental networks has been the emergence of a new "multilayered regulatory system" concentrated among Organization for Economic Cooperation and Development (OECD) countries. ${ }^{24}$ These governments have responded to deepening economic and financial integration and increasing interdependence across a wide range of issues by developing strategies for regulatory cooperation and rapprochement. Transgovernmental networks have proliferated in response to these needs. However, as an OECD study concluded in 1994, the new forms of governance necessary to make regulatory cooperation work cannot simply follow function. They must instead be managed within a principled framework designed not

21. See IMF Factsheet, supra note 19.

The Financial Stability Forum was initiated by the Finance Ministers and Central Bank Governors of the Group of Seven industrial countries in February 1999, following a report on international cooperation and coordination in the area of financial market supervision and surveillance by the President of the Deutsche Bundesbank. In addition to representatives from the Basle Committee, IOSCO, and LAS, its members include "senior representatives from national authorities responsible for financial stability in significant international financial centers;" international financial institutions such as the BIS, the MMF, the OECD, and the World Bank; and "committees of central bank experts."

Id. For a discussion of additional networks created by the Basle Committee, IOSCO, and the IAIS, such as the Joint Forum on Financial Conglomerates and the Year 2000 Network, see Slaughter, Governing the Global Economy, supra note 1, at 186-88.

22. Zaring, supra note 20, at 285 (pointing out that the Restatement (Third) of Foreign Relations does not include these types of organization); see also Porter, supra note 20, at 4-5.

23. Picciotto, Networks in International Economic Integration, supra note 1, at 1039.

24. Jacobs, supra note 1 , at 17 . 
only to improve their effectiveness and the quality of their output, but also to "protect democratic processes."25

Third, the most concentrated site for multilevel governance, and particularly transgovernmental regulatory interactions, is the EU itself. Following the completion of the single market in 1992, the EU has emerged as a "regulatory state," exercising power through rulemaking rather than taxing and spending. ${ }^{26}$ Responding to the challenge of harmonizing or at least reconciling the regulations of its diverse and growing members, the EU has developed a system of "regulation by networks," located in the Council of Ministers (Council) and the complex process of "comitology" that surrounds Council decisionmaking. ${ }^{27}$ The question now confronting legal scholars and political theorists is how decisionmaking by networks of national regulators fits with varying national models of democracy. ${ }^{28}$

Fourth is the emergence of a system of "transatlantic governance" to help foster and manage the increasingly dense web of transatlantic economic cooperation. ${ }^{29}$ Although transatlantic regulatory relations may seem to be only a subset of the larger multilayered regulatory system just discussed, they take place within the framework of several specific initiatives launched by heads of state. As described by Mark Pollack and Gregory Shaffer, transatlantic governance involves cooperation at the intergovernmental level, the transgovernmental level, and the transnational level. ${ }^{30}$ The evolution of transatlantic relations during the 1990 s has thus spawned questions conceming the interrelationship and relative importance of these three levels. ${ }^{31}$

Finally, transgovernmental networks play an important role in several recent and still actively debated theories of compliance with international rules. Abram and Antonia Chayes and Harold Koh have emphasized the importance of regular interaction, dialogue, and "jawboning" among networks

25. Id. at 35-36.

26. Giandomenico Majone, The European Community as a Regulatory State, 5 COLLECTED COURSES OF THE ACADEMY OF EUROPEAN LAW 321,340 (1994).

27. Renaud Dehousse, Regulation by Networks in the European Community: The Role of European Agencies, 4 J. EUR. PUB. POL'Y 246, 254 (1997).

28. Several recent articles exploring this question include Joshua Cohen \& Charles Sabel, DirectlyDeliberative Polyarchy, 3 EuRO. L. J. 313 (1997); Christian Joerges \& Juergen Neyer, From Intergovernmental Bargaining to Deliberative Political Processes: The Constitutional Comitology, 3 EuRo. L.J. 273 (1997); see also the articles collected in EUROPEAN COMMTTEES: SOCLAL REGULATION, LAW AND Poumcs (Christian Joerges \& Ellen Vos, eds., 1999).

29. See Transatlantic Governance In the Global Economy (Mark A. Pollack \& Gregory C. Shaffer eds., 2001).

30. Id., at ch. 1 .

31. Id. These are the questions animating the case studies collected in this volume. 
of government officials at both the international and transnational levels. ${ }^{32}$ Both theories penetrate the traditional black box of the State to focus on the activities of specific government institutions and officials.

\section{A TYPOLOGY OF TRANSGOVERNMENTAL NETWORKS}

Building on this earlier work and current empirical observation, it is possible to identify three different types of transgovernmental regulatory networks based on the different contexts in which they arise and operate. First are those networks of national regulators that develop within the context of established international organizations. Second are networks of national regulators that develop under the umbrella of an overall agreement negotiated by heads of state. And third are the networks that have attracted the most attention over the past decade-networks of national regulators that develop outside any formal framework. These networks arise spontaneously from a need to work together to address common problems; in some cases, members interact autonomously enough to require the institutionalization of their activities in their own transgovernmental regulatory organizations. ${ }^{33}$

These three types are interlinked in many ways; some may seem such a standard part of the international furniture as to be beneath notice, while others compete directly with actual or possible international organizations. For present purposes, however, each raises different accountability problems. It is therefore valuable to develop a typology as a first step toward pinpointing precisely what "lack of accountability" means in this context and what specific steps might be taken to address it.

\section{A. Government Networks Within International Organizations}

What's new? National government officials have always networked within international organizations; once the heads of state have gone home, the task of actually getting on with the mission of a particular institution, however fragile and sketchy, falls to the national government officials in the issue area concerned. Indeed, depending on the issue area, national officials often play a role even before the creation of the institution-U.S. Treasury Secretary

32. See CHAYES \& CHAYES, supra note 6; Harold Hongju Koh, Transnational Legal Process, 75 NEB. L. REV. 181, 181-207 (1996).

33. Zaring refers to these as "international financial regulatory organizations." Zaring, supra note 20 , at 285. 
Harry Dexter White, for example, was certainly present at Bretton Woods. ${ }^{34}$ But once an institution has been established - whether to regulate international labor, environmental protection, health, international criminal activity, or the sprawling and increasingly untidy global markets-it will certainly fall to the national ministries or agencies charged with the particular issue area in question to work with the nascent international secretariat officially charged to represent the organization's interests.

Keohane and Nye describe networks of government ministers within international organizations as embodying the "club model" of international institutions. ${ }^{35}$ Within a particular intergovernmental institution established by treaty, "cabinet ministers or the equivalent, working in the same issue-area, initially from a relatively small number of relatively rich countries, got together to make rules. Trade ministers dominated the GATT; finance ministers ran the IMF; defense and foreign ministers met at NATO; central bankers at the Bank for International Settlements (BIS)." ${ }^{33}$ This mode of operation was efficient for participating governments because the relatively small and like-minded number of ministers involved formed a negotiating "club" in which they reached agreements and then reported them to national legislatures and publics."

The OECD is perhaps the quintessential example of a transgovernmental regulatory network within an established international institution. Its primary function, at least in recent decades, has been to convene government officials in specific issue areas for the purpose of addressing a common problem and making a recommendation or promulgating a model code for its solution..$^{38}$ As discussed above, the EU Council of Ministers operates the same way, although Council members exercise actual decision-making power. Finally, in some cases, the secretariat of an international institution deliberately encourages the formation of a network of officials from specific governments to act as a

34. Richard N. Gardner, Sterling-Dollar Diplomacy in Current Perspective: The Origins AND THE PROSPECTS OF OUR INTERNATIONAL ECONOMIC ORDER (1969).

35. Robert O. Keohane \& Joseph S. Nye, Jr., The Club Model of Multilateral Cooperation and Problems of Democratic Legitimacy. Paper Prepared for the American Political Science Convention, Washington, D.C., Aug. 31-Sept. 3, 2000, available at http://www.ksg.harvard.edu/cbg/trade/keohane.htm (last visited Mar. 28, 2001) [hereinafter Keohane \& Nye, Club Model of Multilateral Cooperation].

36. Id. at "The Club Model of Multilateral Cooperation."

37. Id.

38. For an excellent brief overview of the OECD's origins and current activities, see James Salzman, Labor Rights, Globalization and Institutions: The Role and Influence of the Organization for Economic Cooperation and Development, 21 MICH. J. INT'L L. 769, 776-83 (2000). The OECD website is also a rich source of information. See, e.g., ORGANISATION FOR ECONOMIC CO-OPERATION AND DEVELOPMENT, What is OECD?, at http://www.oecd.org/about/general/index.htm. (last visited Mar. 28, 2001). 
negotiating vanguard in developing new rules that are ultimately designed to apply to all members. ${ }^{39}$

\section{B. Government Networks Within the Framework of an Executive Agreement}

The second type of transgovernmental network is a more striking form of governance in that it emerges outside a formal international institution. Nevertheless, the members of these networks operate within a framework agreed on at least by the heads of their respective governments.

Transatlantic, transgovernmental interactions specifically authorized and encouraged by executive agreement are a good recent example. Pollack and Shaffer chronicle a series of executive agreements between the U.S. President and the President of the EU Commission to foster increased cooperation, including the Transatlantic Declaration of 1990, the New Transatlantic Agenda of 1995 (with a Joint U.S.-EU Action Plan attached), and the Transatlantic Economic Partnership agreement of $1998 .{ }^{40}$ Each of these agreements spurred "ad hoc meetings between lower-level officials," as well as among business enterprises, environmental, and consumer activist groups "on issues of common concern." These meetings, in turn, have become "a potential catalyst for transatlantic policy convergence." ${ }^{.41}$ Many of these networks of lower level officials were emerging anyway, for functional reasons, but they undoubtedly received a boost from agreements at the top.

Another example is the web of transgovernmental networks among financial officials that has emerged as the pragmatic answer to calls for "a new financial architecture for the 21st century" in the wake of the Russian and East Asian financial crises of 1997 and $1998 .{ }^{42}$ Notwithstanding a wide range of proposals from academics and policymakers, including one for a global central bank, ${ }^{43}$ what actually emerged was a set of financial reform proposals from the

39. See TRANSNATIONAL RELATIONS, supra note 12, at 54 (describing the ways in which international organizations "facilitate face-to-face meetings among officials in 'domestic' agencies of different governments; suggesting that 'strategically minded secretariats' of international organizations could plan meetings with an eye to encouraging such contacts; and identifying several networks involving both transgovernmental and transnational contacts specifically created by international organizations.").

40. POLLACK \& SCHAFFER, supra note 29, 14-17.

41. Id. at 17.

42. Speech by President Clinton to the Council on Foreign Relations, Sept. 14, 1998 available at http:/www.geocities.com/CapitolHill/2807/emailspeech.html (last visited May 8, 2001). Clinton was echoing calls by British Prime Minister Tony Blair to build a "hew Bretton Woods for the next millennium." Global Finance. Don't Wait Up, ECONOMIST, Oct. 3, 1998, U.S. edition, at 83.

43. Jeffrey N. Garten, Needed: A Fed for the World, N.Y. TIMES, Sept. 23, 1998. Two British economists, John Eatwell and Lance Taylor, proposed a World Financial Authority. Don 't Wait Up, supra 
G-22 that were subsequently endorsed by the G-7 (now the G-8). ${ }^{44}$ Largely to counter the Eurocentric bias of the G-7, the Basle Committee, and the IMF's "interim committee," which is itself a group of finance ministers, the United States pushed for the formation of the G-22 in 1997 to create a transgovernmental network of officials from both developed and developing countries. ${ }^{45}$ The East Asian countries most affected were happy to leave the details of financial reform to the G-22, in lieu of any grander vision. ${ }^{46} \mathrm{~A}$ number of the more sweeping reform proposals suggested the formation of still other networks - a G-16 or a G-15. ${ }^{47}$

The actual work done within these networks-policy recommendations, new sets of standards, and model codes-is done by finance ministers, securities regulators, central bankers, and other officials responsible for overseeing national economic policy. But, again, they are convened and approved by heads of state, often simply through informal agreements or joint communiqués. In fact, when the G-7 issued a statement on global economic reform in October 1998, the statement itself was issued by finance ministers and central bank governors, accompanied by a parallel statement from heads of government. ${ }^{48}$

\section{Spontaneous Government Networks-Agencies on the Loose?}

In 1974, Keohane and Nye wondered "whether the common interests of central bankers in a stable currency system have been implemented as fully by transgovernmental contacts as they might have been." ${ }^{\prime \prime 9}$ In 2001, the complaint

note 42.

44. Robert Chote, Economics Notebook: A World in the Woods, FIN. TnMEs (London), Nov. 2, 1998, at 20.

45. Don't Wait Up, supra note 42, at 82-83. In November 1997, President Clinton and other leaders of the Asia-Pacific Economic Forum (APEC) announced the temporary creation of the Group of 22 to advance global financial reform. See IMF Factsheet, supra note 19. Its original members included finance ministers and central bank governors from the G-7 (Canada, France, Germany, Italy, Japan, the United Kingdom, and the United States) and 15 countries with growing markets (Argentina, Australia, Brazil, China, Hong Kong SAR, India, Indonesia, Korea, Malaysia, Mexico, Poland, Russia, Singapore, South Africa, and Thailand). Id. It subsequently evolved into the G-33 and then the G-20. Id.

46. APEC's Family Feud, ECONOMIST, Nov. 21-27, 1998 at 41.

47. Jeffrey Sachs proposed the creation of a G-16, composed of the G-8 plus "eight counterparts from the developing world." The group would "not seek to dictate to the world, but to establish the parameters for a renewed and honest dialogue." Jeffrey Sachs, Making lt Work, ECONOMIST, Sept. 12, 1998, at 23. Jeffrey Garten proposed a G-15 (the G-8 plus 7 ) to monitor the actions of a new global central bank. Garten, supra note 43.

48. Chote, supra note 44.

49. Transgovernmental Relations, supra note 14, at 51 . 
is the opposite. The transgovernmental regulatory networks that have spurred the greatest concern are those that have emerged outside formal intergovernmental agreements, whether treaties or executive agreements. The Basle Committee is the leading suspect. The image of national regulators coming together of their own volition and regularizing their interactions as either a network or a networked organization raises the specter of agencies on the loose.

These spontaneous networks themselves divide into two further categories. The first category consists of the networks that institutionalize themselves as transgovernmental regulatory organizations. The founding and designated members of these organizations are domestic agencies, or even subnational agencies such as provincial or State regulators. These organizations tend to operate with a minimal physical and legal infrastructure. Most lack a foundational treaty and operate under only a few agreed upon objectives or bylaws. Nothing they do purports to be legally binding on the members, and they typically have few or no mechanisms for formal enforcement or implementation. Rather, these functions are left to the members themselves. ${ }^{50}$

The second category comprises agreements between the domestic regulatory agencies of two or more nations. The last few decades have witnessed the emergence of a vast network of such agreements, effectively institutionalizing channels of regulatory cooperation between specific countries. These agreements embrace principles that can be implemented by the regulators themselves; they do not need further approval by national legislators. The widespread use of memoranda of understanding and even less formal initiatives has sped the growth of transgovernmental interaction exponentially, in contrast to the lethargic pace at which traditional treaty negotiations proceed. Furthermore, while these agreements are most commonly bilateral arrangements, they may also evolve into multilateral arrangements, offering greater scope but less formality than traditional transgovernmental organizations.

50. Zaring, supra note 20 , at 287. 


\section{PINPOINTING ACCOUNTABILITY CONCERNS}

Transgovernmental interactions within each of these three categories raise distinct, if often interrelated, accountability concerns. Accountability itself is such a complex concept, with many different definitions in different contexts and according to different political theories, that it makes little sense to address it apart from specific factual situations. It can stand for democracy, legitimacy, control, responsiveness, and many other attributes of an ideal government or governance structure.

Nevertheless, the umbrella of accountability captures a core point. Keohane and Nye put it sharply: "Even in democratic societies, the borderline between legitimate transgovernmental behavior and treason may be unclear." This section identifies specific accountability concerns within each category. It focuses on responses to these concerns primarily in the third category of transgovernmental networks outside the framework of a treaty or an executive agreement.

\section{A. The Accountability of Transgovernmental Interaction within International Organizations}

The traditional working assumption about international organizations is that if they are duly established by treaty, with the attendant national ratification procedures, then they exercise only delegated powers from the Member States and therefore do not raise any formal accountability concerns. That is not to say that they do not arouse suspicion-often intense suspicion-among certain domestic constituencies in Member States. Within the United States, for instance, the United Nations (UN) has been accused of using a fleet of "black helicopters" to threaten loyal U.S. citizens. ${ }^{52}$ But both the executives and the legislatures of participating States have had to approve the organization's activities and could at least theoretically withdraw their approval by restricting funding, or even withdrawing from the treaty.

In practice, of course, as Keohane and Nye again pointed out in 1974, international organizations can be vital sites for different government officials,

51. Transgovernmental Relations, supra note 14, at 49.

52. See Daniel L. Gebert, Sovereignty under the World Heritage Convention: A Questionable Basis for Limiting the Federal Land Designation Pursuant to International Agreements, 7 S. CAL. INTERDISC. L.J. 427, 429-30 (1998) (citing John M. Goshko, U.N. Becomes Lightning Rod for Rightist Fears, WASH. POST, Sept. 23, 1996, at A1); David B. Kopel \& Paul M. Blackman, Can Soldiers Be Peace Officers?: The Waco Disaster and the Militarization of American Law Enforcement, 30 AKRON L. REV. 619,654 (1997). 
including heads of state, to form policy coalitions with their foreign counterparts to strengthen their hand in domestic bureaucratic struggles. ${ }^{53}$ The impact of the international organization is to "transform potential or tacit coalitions into explicit ones," as well as to form alliances between an organization's secretariat and relevant national officials. ${ }^{54}$ The very existence of the international organization symbolized member governments' recognition of the need for cooperation and joint decisionmaking in a particular area and hence helped to legitimize transgovernmental activity. ${ }^{55}$

By 2000 , public doubts and suspicion about the activities of at least certain international organizations had increased sharply, often due precisely to the perception that elite transgovernmental interactions were taking place within them. The "club model" had broken down. ${ }^{56}$ In response, organizations ranging from the World Trade Organization to the UN to the OECD have instituted a raft of "outreach efforts" to global civil society, enhancing transparency, hosting NGO meetings, and acknowledging and promoting "global policy networks." organizations themselves may simply prove too tempting a target for their detractors. But in these cases, the transgovemmental activity within these organizations and the activity of the organization itself seem indistinguishable; hence, the issue is more complex than can be addressed here. ${ }^{58}$

\section{B. Transgovernmental Activity within the Framework of Executive Agreements}

Transgovernmental activity within the framework of executive agreements is often less visible than transgovernmental networks within established institutions. Further, the very fact of their creation by executive agreement rather than by treaty means that they have not been approved by the legislature, even prospectively. And the legitimacy provided by head of state

53. Transgovernmental Relations, supra note 14, at 50-55.

54. Id. at 52.

55. Id. at 50 .

56. See Keohane \& Nye, Club Model of Multilateral Cooperation, supra note 35.

57. See, e.g., World Trade Organization, WTO \& NGOs: Relations with Nov-Govemmental Organizations/Civil Society, at http:/www.wto.org/english/forms_e/ngo_e/intro_e.htm (last visited May 15, 2001); Kofi A. Annan, 'We the Peoples:' The Role of the United Nations in the 21 st Century, at http:/www.un.org/millennium/sg/report (last visited May 15, 2001) [hereinafter Millennium Report]; http://www.oecd.org.

58. Roberto M. Unger, The Really New Bretton Woods, in THE FRANCLAL SYSTEM UNDER STRESS 11 25 (Marc Uzan ed., 2000) (arguing against the "supranational technocracy" of the IMF and the World Bank). 
approval may be negated if heads of state are themselves engaging in "transgovernmental collusion."

John Peterson finds evidence of exactly such collusion in his study of U.S.-EU efforts to implement a New Transatlantic Agenda in the 1990s. ${ }^{59} \mathrm{He}$ argues that American and European chiefs of government have colluded with one another to reward some domestic interest groups over others. ${ }^{60}$ Further, "a central ambition of the New Transatlantic Agenda ... is to manufacture the same sort of complicity between administrations and societies, as distinct from intergovernmental elites, through new transgovernmental and transnational exchanges." ${ }^{.61}$ Pollack and Shaffer agree, noting that the entire set of transatlantic initiatives can be understood as a joint effort between the U.S. Administration and the EU Commission to "institutionalize their joint preferences" for more transatlantic and global trade liberalization, as well as to strengthen key domestic constituencies. ${ }^{62}$

Such accounts can legitimately raise fear and concern among disfavored domestic constituencies, in this case consumers, environmentalists, and labor. When the head of state throws his or her power behind some kinds of transgovernmental (and transnational) contacts but not others, without legislative input, it can seriously tilt the domestic political playing field. Observers could draw a similar conclusion from the practice, noted above, of accompanying a statement by finance ministers and central bankers with a parallel statement by heads of government. These interactions by heads of state and the transgovernmental relations resulting from them are analogous, at least for the U.S. and the EU Commission, to the domestic innovation of "presidential administration," whereby the head of state controls the political agenda by executive decree rather than collaborative legislation. ${ }^{63}$ The response to the resulting accountability concerns will likely be legislative, prodded by the disaffection of outmaneuvered domestic constituencies.

59. See generally John Peterson, Get Away From Me Closer, You're Near Me Too Far: Europe and America after the Uruguay Round, in POLLACK \& SHAFFER, supra note 29, at 45-72.

60. Id. at 46.

61. Id.

62. Mark A. Pollack \& Gregory C. Shaffer, Who Governs?, in POLLACK \& SHAFreR, supra note 29, at 295.

63. Elena Kagan, Presidential Administration, 104 HARV. L. REv. (forthcoming 2001). 


\section{Spontaneous Transgovernmental Networks}

Transgovernmental networks that arise outside the framework of international organizations and executive agreements are most likely to spawn fears of runaway technocracy. That a regulatory agency would reach out on its own to its foreign counterparts, even in an effort to solve common problems, raises the possibility not only of policy collusion, whereby transgovernmental support can be marshaled against domestic bureaucratic opponents, but also of the removal of issues from the domestic political sphere through deliberate technocratic de-politicization. ${ }^{64}$

A wide range of possible measures can combat these perceptions and enhance public awareness of these networks and even participation in them. ${ }^{65}$ Creating a well-serviced website for example, can make a network real by making it virtual. ${ }^{66}$ A further step toward enhanced transparency would be to create the global equivalent of EU "information agencies," entities that "lack a coercive power of their own," but which instead "provide policy-makers with the information they need to carry out their policies." ${ }^{167}$ Enhanced legislative oversight of any domestic agency's foreign activities would help; better still might be the formation of legislative networks-perhaps of representatives of key legislative committees-to share information and coordinate efforts to pass parallel domestic legislation. ${ }^{68}$ In addition, as is already happening, transgovernmental networks can be folded into larger "mixed networks" of governmental and private actors. ${ }^{69}$ In his Millennium Report, the UN Secretary General explicitly called for the formation of "global policy networks" involving a wide range of public and private actors. ${ }^{70}$

Another quite different response to accountability concerns regarding spontaneous networks is the claim that they do not exercise actual power-that they are mere "talking shops." With few exceptions, such as the Basle Committee, participants in these networks cannot actually make rules or adopt

64. See Picciotto, Networks in International Economic Integration, supra note 1, at 1037.

65. I have spelled out a number of these measures at some length in a forthcoming essay. See AnneMarie Slaughter, Agencies on the LOOse? in TRANSATLANTIC REGULATORYCO-OPERATION, 521 -46 (Geotge Bermann et al, eds.) (forthcoming 2001) [hereinafter Slaughter, Agencies on the Loose].

66. Anne-Marie Slaughter, Virtual Visibility, FOREIGN POL'Y $84-85$ (Nov/Dec. 2000).

67. Dehousse, supra note 27, at 254, citing Majone, supra note 26.

68. See Slaughter, Real New World Order, supra note 3, at 197 (describing existing legislative networks).

69. POLLACK \& SHAFFER, supra note 29, at 301 (finding the existence of such networks in the transatlantic context).

70. Millennium Report, supra note 57. 
policies. They can only disseminate information and bring back recommendations and proposals for consideration through the normal domestic legislative or agency rulemaking process.

This view of transgovernmental networks is shortsighted. It misses a key dimension of the exercise of power in the Information Age. The "talking shops" generate compilations of best practices, codes of conduct, and templates for everything from a memorandum of understanding to an environmental assessment review. As a senior official from the World Bank recently noted, the dissemination of information has played a far greater role in triggering policy convergence in various issue areas than more deliberate and coercive attempts."

This result is not surprising. In a world awash with information, credible and authoritative information is at a premium. ${ }^{72}$ Even more valuable is a distillation and evaluation of information from many different sources. Recommended rules and practices compiled by a global body of securities regulators or environmental officials offer a focal point for convergence. Equally important, they offer a safe harbor for officials who are looking for guidance and besieged by consultants.

Yet should government officials be held accountable for either disseminating or using information? As new forms of global governance emerge wielding informational power, and probably engaging in new forms of informational politics, the very concept of accountability-even accepting its current complexity-must grow and change. These are questions not only for lawyers and public policymakers, but also for political theorists.

\section{EXTERNAL ACCOUNTABILITY}

Thinking about accountability in terms of new forms of power highlights the distinction between internal and external accountability. To a domestic public, accountability refers to the relationship between it and its government officials. Yet in analyzing the impact of the information compiled and disseminated by transgovernmental networks, the flow of such information is

71. Andres Rigo, Law Harmonization Resulting From the Policies of International Financial Institutions: The Case of the World Bank, speech delivered at $A$ Conference on Globalization and the Evolution of Legal Systems, University of Ottawa, (Oct., 2000). See generally, CoMMITMENT AND COMPLIANCE: The ROle of NON-BINDING NORMS IN THE INTERNATIONAL. Legal SySTEM (Dinah Shelton ed., 2000).

72. Robert O. Keohane \& Joseph S. Nye, Jr., Power and Interdependence in the Information Age, 77 FOREIGN AFF. 81 (Sept./Oct. 1998). 
far more likely to proceed from developed country government officials to developing country government officials. This asymmetry raises the issue of accountability in the global community, or the "external" accountability of one nation to another.

Addressing this question in detail, however, is beyond the scope of this Article. I have elsewhere advanced a set of principles that could provide a framework for regulating transgovernmental relations, at least in the context of transgovernmental conflict. ${ }^{73}$ First, the context of transgovernmental relations should be understood differently from intergovernmental relations. Cooperation is to be valued, but not necessarily cemented. Conflict is positive, the vehicle for building trust and shared understandings over time. ${ }^{74}$ In a word, conflict must be treated like conflict in a liberal domestic political system, rather than conflict in the world of diplomacy. It is a natural and normal part of politics, ${ }^{75}$ not a danger to be dampened.

Second, within this altered context, government officials engaged in interactions with their foreign counterparts should be guided by the principles of legitimate difference and positive comity. Legitimate difference reflects the established principle in conflicts of law that difference, in and of itself, should be respected as long as it falls within a broad zone circumscribed by fundamental principles of the common weal. ${ }^{76}$ As a working principle, it requires presumptive recognition of foreign rules rather than the automatic acceptance mandated by mutual recognition. Positive comity is a companion principle. Developed in the context of U.S.-EU antitrust relations, it requires officials not simply to recognize foreign rules and practices, but also to give foreign officials the first opportunity to take action on problems that fall within their jurisdiction. ${ }^{77}$

73. Slaughter, Agencies on the Loose, supra note 65 , at $521-46$.

74. See Albert O. Hirschman, A Propensity to Self-SubVersion 235 (1995) ("Social conflicts themselves produce the valuable ties that hold modem democratic societies together and lend them the strength and cohesion they need.").

75. Id.

76. Loucks v. Standard Oil Co., 120 N.E. 198 (N.Y. 1918).

The courts are not free to enforce a foreign right at the pleasure of the judges, to suit the individual notion of expediency or faimess. They do not close their doors unless help would violate some fundamental principle of justice, some prevalent conception Id. at 201. of good morals, some deep-rooted tradition of the common weal.

77. Agreement Regarding the Application of their Competition Laws, Sept. 23, 1991, E.C.-U.S., 30 I. L. M. 1491. Article V of the Agreement provides that if Party A believes that its "important interests" are being adversely affected by anticompetitive activities that violate Party A's competition laws but occur within the territory of Party B, Party A may request that Party B initiate enforcement activities. Id. at 1056 59. Thus, Government B, in deference to Government A, is expected to consider enforcement steps that it 
These principles would apply only to some kinds of transgovernmental relations, notably those in which action by one government agency could harm its foreign counterpart through nonrecognition of the foreign rule or extraterritorial action. They might also be adapted to guide the formation and evolution of transgovernmental networks in the sense that compilers of codes of best practices might be required to cast a broader net. Their principal importance at this stage of their analysis is to put the larger issue of global accountability on the table.

\section{CONCLUSION}

Transgovernmental networks are an increasingly important form of global governance. They are not new, but they are particularly notable as a governance strategy in an era of globalization. They arise in a number of different contexts-within international organizations, within the framework of an executive agreement, and spontaneously in response to common problems.

Each of these three categories raises distinct, if overlapping, accountability problems. Transgovernmental networks within international organizations used to be largely invisible and relatively unproblematic; they now face the challenge of relegitimizing the entire organization in the face of rising domestic opposition. Transgovernmental networks within the framework of an executive agreement raise the specific problem of executive collusion to circumvent national legislatures. And spontaneous government networks evoke images of national regulators reaching out across borders to make the world safe for bureaucracy.

It is relatively easy to generate specific measures to enhance transparency and public access in each category. Administrative lawyers who specialize in resolving such questions at the domestic level can now turn their attention to transgovernmental regulatory activity. The deeper issue, however, is the way in which regulatory networks most frequently exercise power-through the distillation and dissemination of authoritative and credible information to their members throughout the world. When does borrowing and implementing models and ideas from abroad contravene a domestic political mandate? And

might not otherwise have taken. For a more detailed account of the development of this principle, see Slaughter, Agencies on the Loose, supra note 65, at 538-42. 
when does the impact of global information flows primarily from developed to developing countries raise issues of global accountability? These are the theoretical challenges posed by transgovernmental governance. 
